\title{
SOCIO-CULTURAL FACTORS AFFECTING FEMALE HIGHER EDUCATION: AN ANALYSIS OF CHITRAL, PAKISTAN
}

\author{
Ihtisham Uddin \\ Visiting Faculty \\ Department of Political Science \\ GCU Lahore \\ ihtishamuddincl@gmail.com \\ Dr. Ahmad Raza Khan \\ Assistant Professor \\ Department of Political Science \\ GCU Lahore \\ ahmadraza@gcu.edu.pk \\ Dr. Fauzia Ghani \\ Assistant Professor \\ Department of Political Science \\ GCU Lahore \\ fauziaghani@gcu.edu.pk
}

\begin{abstract}
:
Higher education signifies the social and economic development of states. Higher education helps society excel in various professions and technical sectors. The progress and prosperity of a society primarily depend on education. Women's education holds prominence in the modern world. No society can develop or can sustain its development without educating its women. They make about 50\% of the world's population and their education connotes the development and progress of a society. Chitral is the least populated district of Khyber Pakhtunkhwa. Due to its exceptional and unique social and ethnic diversity the area has an interesting position on the map of the world. The literacy rate in Chitral is higher among women as compared to other parts of KPK but still receiving higher
\end{abstract}




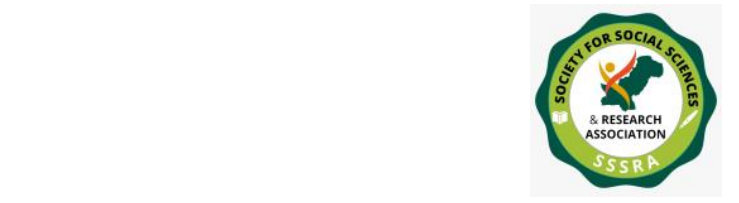

Pak. Journal of Int'L Affairs, Vol 4, Issue 1 (2021)

Socio-Cultural Factors Affecting ...

education is very challenging for girls because of social, economic, infrastructural, and administrative inefficiencies. Social taboos and cultural norms have restricted women of different communities inside their homes and engaged them in household chores. Women in Chitral face many obstacles and challenges in receiving higher education. Social misconception about women's education, religious misapprehensions, and cultural taboos, negative perception of co-education, financial constraints, and lack of proper educational institutions are the significant factors that affect women's higher education. The University of Chitral is the only higher education institution established in 2017. There were no other higher educational institutions before the University of Chitral. The university is still not well developed to meet the demands of higher education especially women's education.

This paper intends to highlight the status of higher education in Chitral, socio-cultural factors affecting higher education of women, the significance of higher education for women in Chitral, and concludes with recommendations and suggestions for a preferable way forward. The researchers had conducted a field survey in Chitral and the data collected has been used in this paper.

Key Words: Women Higher Education, Chitral, KPK, University of Chitral, Coeducation, Socio-Cultural Challenges, Pakistan.

\section{INTRODUCTION}

The United Nations stresses the elimination of gender discrimination against women and fundamental human rights by focusing on women's rights as human rights. Higher education is perceived to be an important investment and has remarkable significance for the socio-economic progress of a society. Higher education helps society to develop in different sectors like it gives professional, scientists, researchers, politicians, teachers, social activists, etc. The progress and prosperity of a society depend on its education. Higher education is respectful cultivation of learning which diverts a society towards peace and prosperity. The social development and progress of a nation depend on its education system; the better the education system of a country, the more the society will develop. Within the time of enhanced globalization, and social awareness across the globe, several issues are being discussed related to different walks of life. Among these issues' women's education is of paramount significance. Women make about $50 \%$ of the 


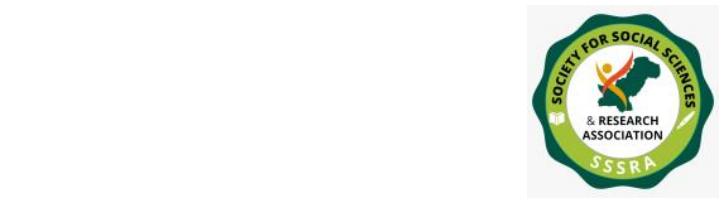

Pak. Journal of Int'L Affairs, Vol 4, Issue 1 (2021)

Socio-Cultural Factors Affecting ...

world population. Their inclusion in the development process is very important for every state. A society can develop and nourish through a system of proper education where the different segments of society inclusively take part in the education process.

District Chitral has a substantial position in the social history of the world because of its unique culture and ethnic diversity. Women's education ratio in district Chitral is slightly greater than other parts of Khyber Pakhtunkhwa, still being least developed area receiving higher education is very challenging for girls. Traveling long distances and harsh weather conditions during winter more intensify the situation for girls' education. This paper aimed to focus upon the status of higher education in Chitral, socio-cultural factors affecting higher education, the significance of higher education for women in Chitral, and conclude with the certain recommendation and suggestion for a possible way forward. An earlier version of these data was used in the unpublished MPhil research thesis of Ihtisham Uddin Department of Political Science GC University Lahore.

\section{$2 \quad$ Status of Women education in Pakistan}

Provision of free and compulsory education from age five to sixteen years without any distinction based on sex or any social status have been stipulated in the constitution of Pakistan ( National Assembly of Pakistan, 2012, Feburary 28), but unfortunately, according to a report published by World Economic Forum Global Human Capital 2017, among 130 nations Pakistan remained at $125^{\text {th }}$ in the education sector, and was declared as the extremely underdeveloped country in the field of education (The Global Human Capital Report 2017, 2017).

In the federal budget of 2020-2021, the government has allocated 83.3 billion on educational expenditures appearing an intangible rise of about $2.5 \%$. Pakistan's public expenditure on education as a proportion to GDP is estimated at $2.3 \%$ within the fiscal year 2019-20, which is the lowest in the region. Compared to international standards the designated budget for education is minimum as of the concurred targets of $15-20 \%$ of the whole budget and 4\% of the GDP (Pakistan Alliance for Girls Education, 2020).

Pakistan is a patriarchal society, where male members of the family handle financial matters, and women spent most of the time inside their homes doing house chores (Eleven Traits of Pak Culture. Odt, n.d.). According to a report of the Ministry of Finance, the education percentage in urban areas of Pakistan is 76 while in rural areas is $51 \%$. The literacy rate of Punjab is 63 percent which is higher than other provinces comparatively followed by Sindh 60 percent, KPK 53 percent, and Baluchistan 44 


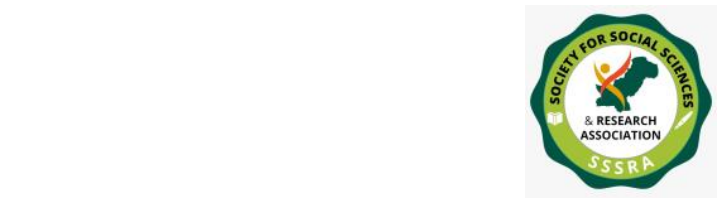

percent respectively (Pakistan Economic Survey, 2008). Higher Education is a significant source for changing society towards peace and progress. Higher education not only empowers women but is also a source of peace and prosperity for the whole nation.

\section{Literature Review:}

\section{$3 \quad$ Importance of higher education for women}

Anant Sadashiv Altekar an ancient historian and archaeologist said that "One of the best ways to understand the spirit of civilization and to appreciate its excellence and realize its limitations, is to study the history of the position of women in it (Altekar, 1938). Higher education plays a phenomenal role in increasing women's confidence. Higher education enhances women's status in family and society. Through higher education, women can better be able to understand their fundamental rights. Higher education will boost selfconfidence among women and will reduce their dependency on others in the better upbringing of their children. By opening modern avenues for career opportunities higher education will also increase women's social mobility (Noreen \& Khalid, 2012).

These ideas reflect the significance and importance of higher education as an essential source of change within a society. The progress and growth of a society depend upon its education system. Education can create new roads and prospects for a bright future.

Further, through higher education, a state can acquire progress and successes which will bring prosperity and will create opportunities for the people to enjoy a better life. It's also beneficial in bringing abrupt changes in the social fabric of society. Higher education brings development in a society in different perspectives as; it weakens gender discrimination, strengthens democratic norms and values, improves self-confidence among individuals, enhances life standards, and helps women to become pioneers and role models for future generations by empowering them. Thus, the World Bank Development Index Report illustrates that in 2017 only $25 \%$ of women were engaged in the labor force and only 7\% have access to financial services (Lund, 2019), which is unfortunately very low compared to the population ratio of $50.8 \%$ male and $49.2 \%$ female (Countrymeters, 2019).

Regarding the role of higher education in Northern Pakistan, Murtaza (2012) in his research highlights that; Higher education plays a substantial role in women uplift and their empowerment, women with higher education can independently take decisions at their homes like; the decision about their future goals, economic investments, marriage priorities, etc. it helps in reduction of gender discrimination and abuse against women. 


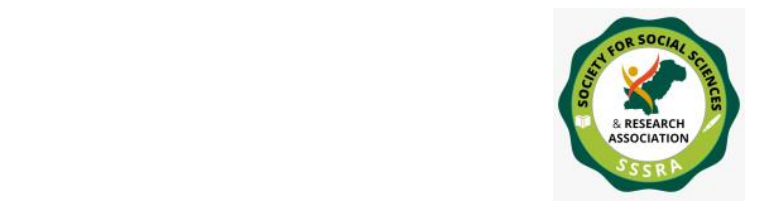

Socio-Cultural Factors Affecting ...

Higher education helps to eliminate the stereotypes against women in society, by making women aware of their rights granted in the constitution (Murtaza, 2012).In Pakistan generally and in tribal areas specifically Socio-cultural taboos have confined women within the parameters of their homes by limiting their career opportunities to specific areas like; teaching, nursing or jobs in banks, etc. (Razzaq, 2016).

\section{$4 \quad$ Higher Education in Chitral}

The education ratio in Chitral is high compared to other areas of Khyber Pakhtunkhwa (AASA Consulting \& GRHO, 2014). According to Dawn report published in 2003, the literacy rate in Chitral was 98 percent and it was the highest in NWFP (Dawn, 2003), but according to a report of Express Tribune published in 2014 almost 37 percent of girls were not enrolled in school, even though Chitral stood $4^{7 \text { th }}$ among 146 countries nationally and $6^{\text {th }}$ among 25 districts of Khyber Pakhtunkhwa. Gender discrimination, sexual harassment, insecurity while traveling, and child labor are some of the important factors which hinder women education in Pakistan according to Human Rights Watch Report 2017(Martinez, 2018, November 12). Literacy rate among women in Chitral is high at school level while in higher education it is very low. Lack of institutions, infrastructural backwardness, harsh weather conditions, socio-cultural taboos, financial constraints aggravates the situation (University of Chitral, 2017).

While discussing the barriers faced by women in their educational life Almina Pradhan says that, In Upper Chitral mostly families do not allow their girls to schools as they consider it against the socio-cultural ad religious norms of the society. Further, she has highlighted that even literates women are discouraged and not permitted to participate in festivals, functions and to go to public places, bazaars, etc, which is socially and culturally not acceptable (Pardhan, 2005).

Abubakar Nazeer Chaudhry (2019) highlights the effects of social norms and cultural constraints as "Social and Cultural taboos inversely affect women better upbringing. Societal and familial factors of not letting women do a decent job will affect the social fabric of the whole country while blocking the avenues of peace and prosperity(Choudhry, Mutalib, \& Ismail 2019). To pursue higher education women face lots of challenges like; burden of house chores, harassment at workplaces, socio-cultural misunderstandings, and financial constraints (Murtaza, 2012). Lack of economic resources, the burden of household religious misinterpretations, lack of educational resources challenge women's education and empowerment in northern Pakistan (Maarit liljergren, 2002). 


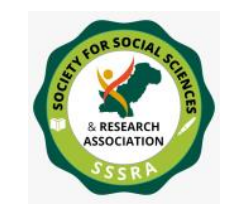

Shah (2015) highlights women's issues and challenges in Higher education as in Chitral women face lots of hardships and trouble in their educational life. Social taboos, financial constraints, and distance of educational institutions are the impediments women face in their educational life (Shah, 2015). Poor accommodation facilities for both female teachers and students, lack of financial resources, lack of teaching staffs, poor monitoring and supporting system are the biggest challenges for women education in northern Pakistan (Kanji \& Ali 2006).

The existing data revealed that women in Chitral face lots of barriers and challenges in getting higher education. Social rectification, cultural taboos, and financial constraints have limited the participation of women in different sectors of life.

\section{$5 \quad$ Conceptual Framework}

After analyzing the literature, the following themes and sub-themes were identified. These themes were used as variables in the study and were tested through a questionnaire.

Table 1.5

\begin{tabular}{|c|l|l|l|}
\hline Sno & \multicolumn{1}{|c|}{ Writer } & \multicolumn{1}{|c|}{ Themes } & \multicolumn{1}{|c|}{ Sub-themes } \\
\hline 1. & Abubakar Nazeer & $\begin{array}{l}\text { Factors affecting women empowerment in } \\
\text { Pakistan. }\end{array}$ & $\begin{array}{l}\text { Education } \\
\text { Employment } \\
\text { Socio-cultural factors } \\
\text { Economic factors }\end{array}$ \\
\hline 2. & Almina Pardhan & Problems Faced & $\begin{array}{l}\text { Socio-cultural constraints } \\
\text { Religious misconception }\end{array}$ \\
\hline 3. & Rakhishanda Shah & Impediments for girl's education & $\begin{array}{l}\text { Social taboos } \\
\text { Financial constraints } \\
\text { Distance of educational } \\
\text { ions }\end{array}$ \\
\hline 4. & Marrit Liljegren & Barriers to women education & $\begin{array}{l}\text { Religious misconception } \\
\text { Lack of economic resource } \\
\text { House chore burden }\end{array}$ \\
\hline 5. & Human Rights Watch Gender Discrimination & $\begin{array}{l}\text { Early marriages } \\
\text { Child labor } \\
\text { Sexual harassment }\end{array}$ \\
\hline
\end{tabular}

These themes and sub-themes were used to develop a questionnaire. These variables were tested through the questionnaire, the validity and claims of these expressions will be 


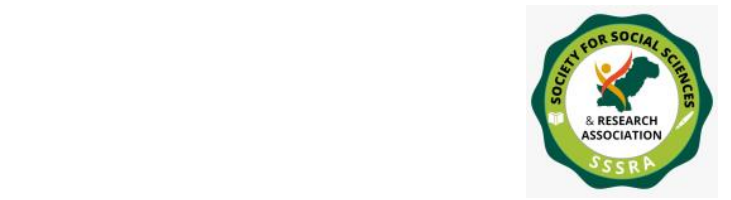

verified through a field survey.

\section{Data Collection}

This study was conducted at the University of Chitral. A total number of 411 female students of MA BS (Hon) and Pass out participated in the study. The sampling method was adopted by taking data from the admission committee, provost office, registrar office, and student facilitation center, Information Technology center, transport management center of the University of Chitral Questionnaire was distributed both manually and in soft form. A total number of 510 questionnaires were distributed among different female students and 411 filled ones were collected.

\section{1: Allocation of more resources to boys than girls}

The respondent's perception was asked in this question to find out whether they believe that parents allocate more resources to boys than girls in Chitral. Generally, it is perceived that families allocate more resources to male members of the society than females.

Table 2.1

\begin{tabular}{|l|c|c|c|}
\hline Sr\# no & Choices & \%age & Frequency \\
\hline 1. & Strongly Disapprove & 15.3 & 64 \\
\hline 2. & Disapprove & 7.2 & 30 \\
\hline 3. & Agree to a little extent & 12.7 & 53 \\
\hline 4. & Agree to a reasonable extent & 21.8 & 91 \\
\hline 5. & Agree to a large extent & 31.7 & 132 \\
\hline 6. & Undecided & 10.8 & 45 \\
\hline 7. & No Response & .5 & 2 \\
\hline 8. & Overall Responses & 100 & 417 \\
\hline
\end{tabular}

The study revealed that almost 32 percent of the respondent have opted "Agree to a large extent" 21.8 percent "Agree to a reasonable extent" and almost 13 percent "Agree to a little extent". This shows the majority of women in Chitral believe that parents allocate more resources to boys than girls for higher education. This reflects the general perception of giving priority to boys over girls in Chitral.

It can also be deduced from the literature review that "In Pakistan mostly parents give preference to their son over their daughters as they believe that investing on their son's education have more prospects and benefits as compared to boys (The Nation, 2015), hence the results show that the stigma of giving preferences to male members of the family is also prevalent in Chitral. 


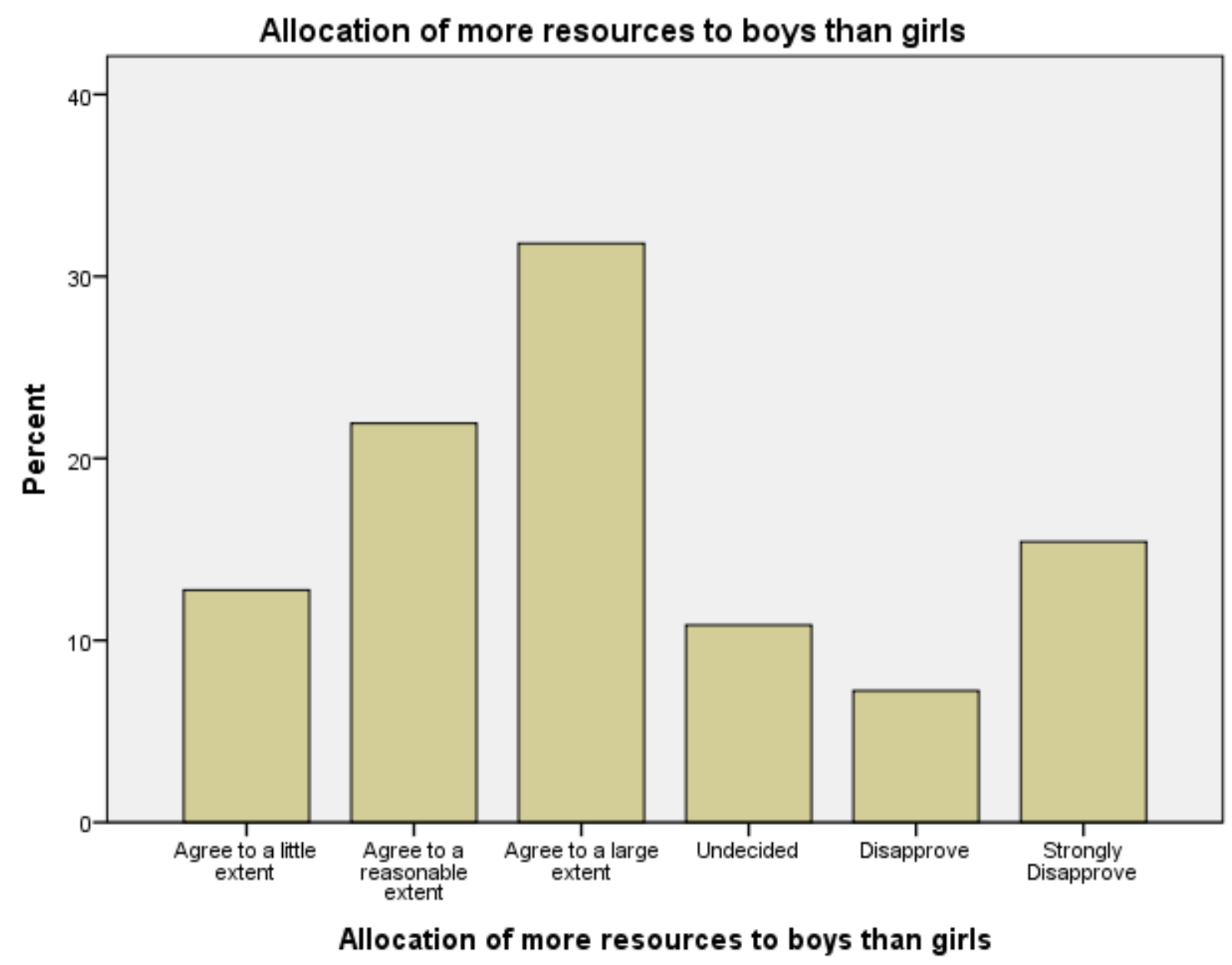

\section{2: Culture related norms restrict higher education for girls}

The question was asked to understand the influence of cultural norms on women's higher education. The respondents were asked how much culture restricts their higher education. 
Table 2.2

\begin{tabular}{|c|c|c|c|}
\hline Sr.\# no & Choices & \%age & Frequency \\
\hline 1. & Strongly Disapprove & 6.2 & 26 \\
\hline 2. & Disapprove & 6.7 & 28 \\
\hline 3. & Agree to a little extent & 18.2 & 76 \\
\hline 4. & Agree to a reasonable extent & 23.3 & 97 \\
\hline 5. & Agree to a large extent & 34.1 & 142 \\
\hline 6. & Undecided & 8.2 & 34 \\
\hline 7. & No response & 3.4 & 14 \\
\hline 8. & Overall responses & 100 & 417 \\
\hline
\end{tabular}

The table shows that a little greater than 34 percent responded "Agree to a large extent" 23 percent to "Agree to a reasonable extent" and 18 percent "Agree to a little extent".

The majority of the participants believe that culture-related norms restrict higher education for girls in Chitral.

The socio-cultural environment is generally believed to have negative impacts on girl's education, as the literature says; socio-cultural taboos compel women to remain inside their homes or they can pursue only limited careers (Razzaq, 2016). This study concedes with the literature. 


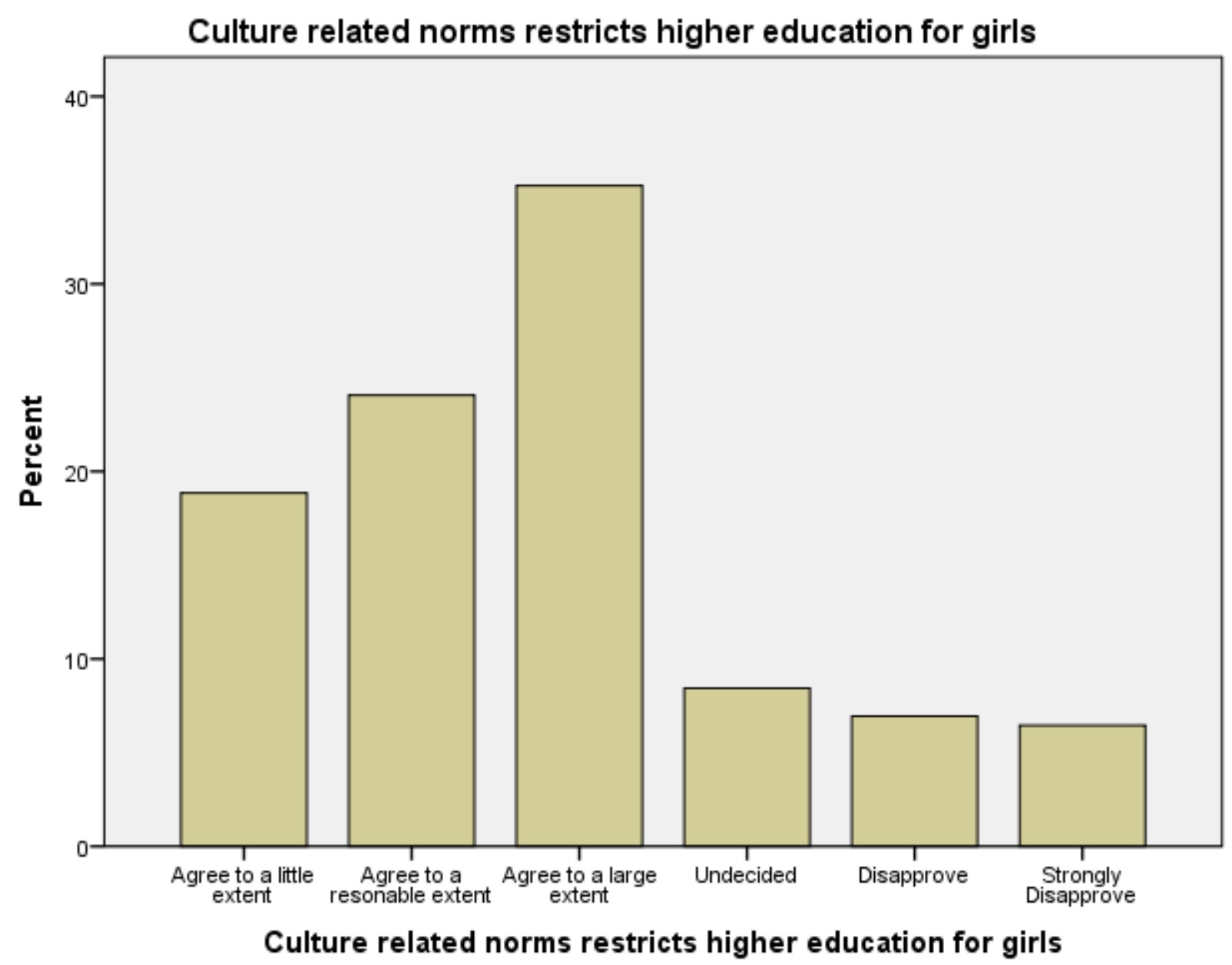

\section{3: Women should be permitted to do business out of Chitral}

The participants were asked if they agree with the statement that women should permit to hold business and to do the job outside Chitral. As it is the least developed area, where employment and job opportunities for females are very rare, except in some NGOs and private sectors like Schools, Colleges, Banks, etc. The majority of highly educated women are not engaged in any profession because of a lack of opportunities. Sociocultural taboos restrict women to engage in private jobs and business outside Chitral. This question was asked to identify the awareness of women in Chitral about their willingness to run a business outside the Chitral district. 
Table 2.3

\begin{tabular}{|l|c|c|c|}
\hline Sr\# no & Choices & \%age & Frequency \\
\hline 1. & Strongly Disapprove & 3.8 & 16 \\
\hline 2. & Disapprove & 4.3 & 18 \\
\hline 3. & Agree to a little extent & 15.1 & 63 \\
\hline 4. & Agree to a reasonable extent & 21.6 & 90 \\
\hline 5. & Agree to a large extent & 45.8 & 191 \\
\hline 6. & Undecided & 6.7 & 28 \\
\hline 7. & No response & 2.6 & 11 \\
\hline 8. & Overall responses & 100 & 417 \\
\hline
\end{tabular}

The above figures show that almost 46 percent of the participants "Agree to a large extent" that women should be allowed to run a business outside Chitral. While 21 percent and 15 percent of the participants "Agree to a reasonable extent" and "Agree to a little extent "respectively.

The data reveals that most women in Chitral believe that families should permit women to run a business outside Chitral. Abubakar Nazeer has discussed different factors which impede women's empowerment. Most women lack education and health facilities. Due to social pressures, families do not allow women to have a job. Women are mostly denied property rights which discourage and obstruct their development and growth (Choudhry, Mutalib, \& Ismail., 2019). The data also concedes with the literature review.

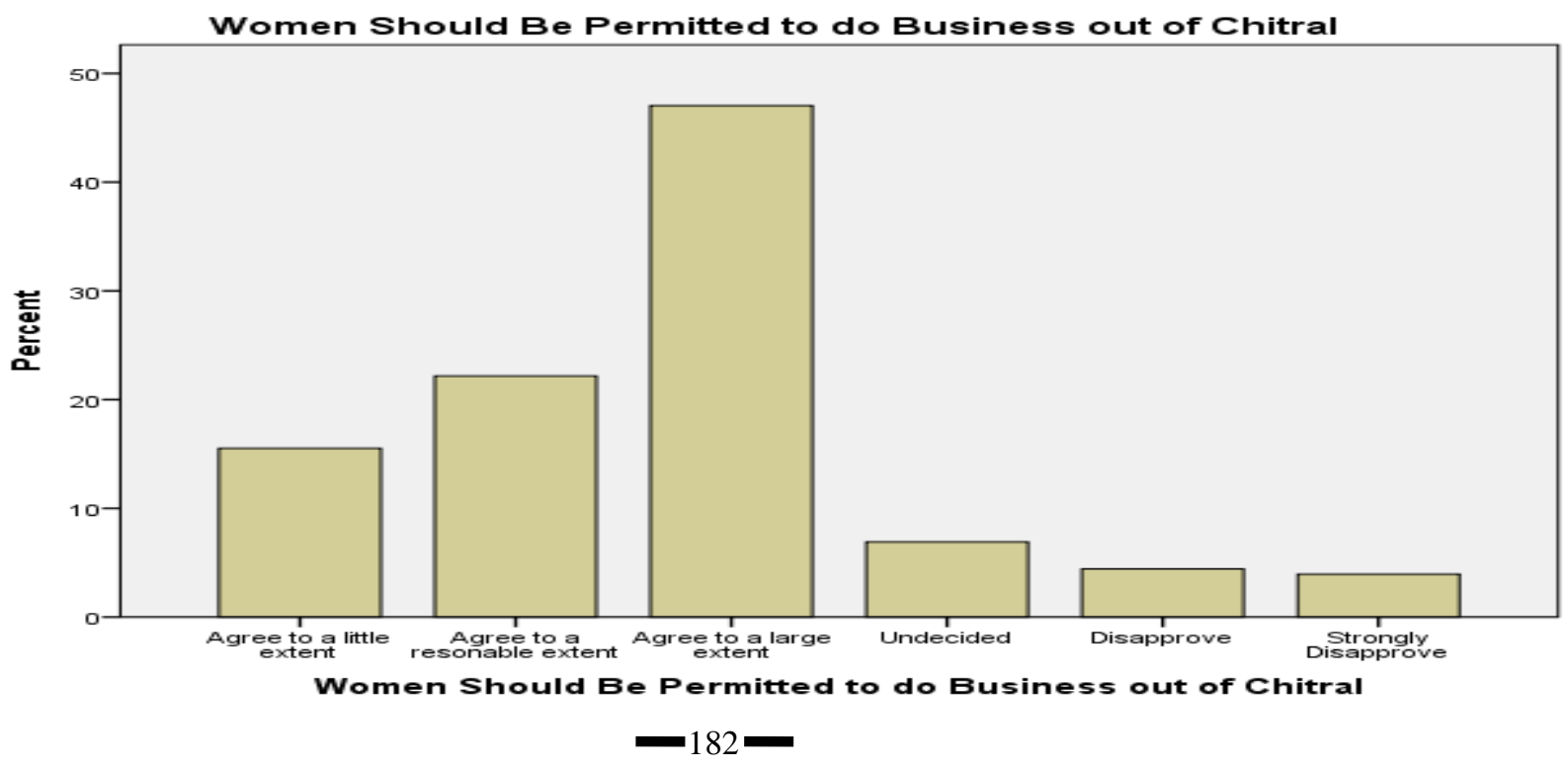




\section{4: Giving Preference to Girls Marriage over Higher Education}

To identify the choices of parents about their daughter's marriage and higher education this question was asked from the participants. Usually, in Pakistan and specifically in tribal areas, parents believe that women should get married as soon as possible and they do not pay any attention to their higher education. This stigma of prioritization of marriage over higher education weakens the development and social fabric of the society. Women's inclusion in different walks of life decreases because of the early marriage phenomena. This social taboo also restricts women within the parameters of the houses and are not allowed to participate in different sectors of the society i.e., social, political, and economic.

Table 2.4

\begin{tabular}{|c|c|c|c|}
\hline Sr\# no & Choices & \%age & Frequency \\
\hline 1. & Strongly Disapprove & 3.6 & 15 \\
\hline 2. & Disapprove & 5.0 & 21 \\
\hline 3. & Agree to a little extent & 13.2 & 55 \\
\hline 4. & Agree to a reasonable extent & 24.5 & 102 \\
\hline 5. & Agree to a large extent & 40.8 & 170 \\
\hline 6. & Undecided & 9.4 & 39 \\
\hline 7. & No response & 3.6 & 15 \\
\hline 8. & Overall responses & 100 & 417 \\
\hline
\end{tabular}

The study revealed that almost $41 \%$ of participants responded "Agree to a large extent", greater than $24 \%$ "Agree to a reasonable extent", and a little more than $13 \%$ opted "Agree to a little extent".

The majority of women are of the view that families in Chitral prefer marriages for their daughters over higher education. The data acknowledges literature that says; " gender discrimination, sexual harassment, child marriages, insecurity while traveling, child labor and attack on educational institutions are some of the dominant barriers to girls education in Pakistan" (Martinez, 2018, November 12 ) . 


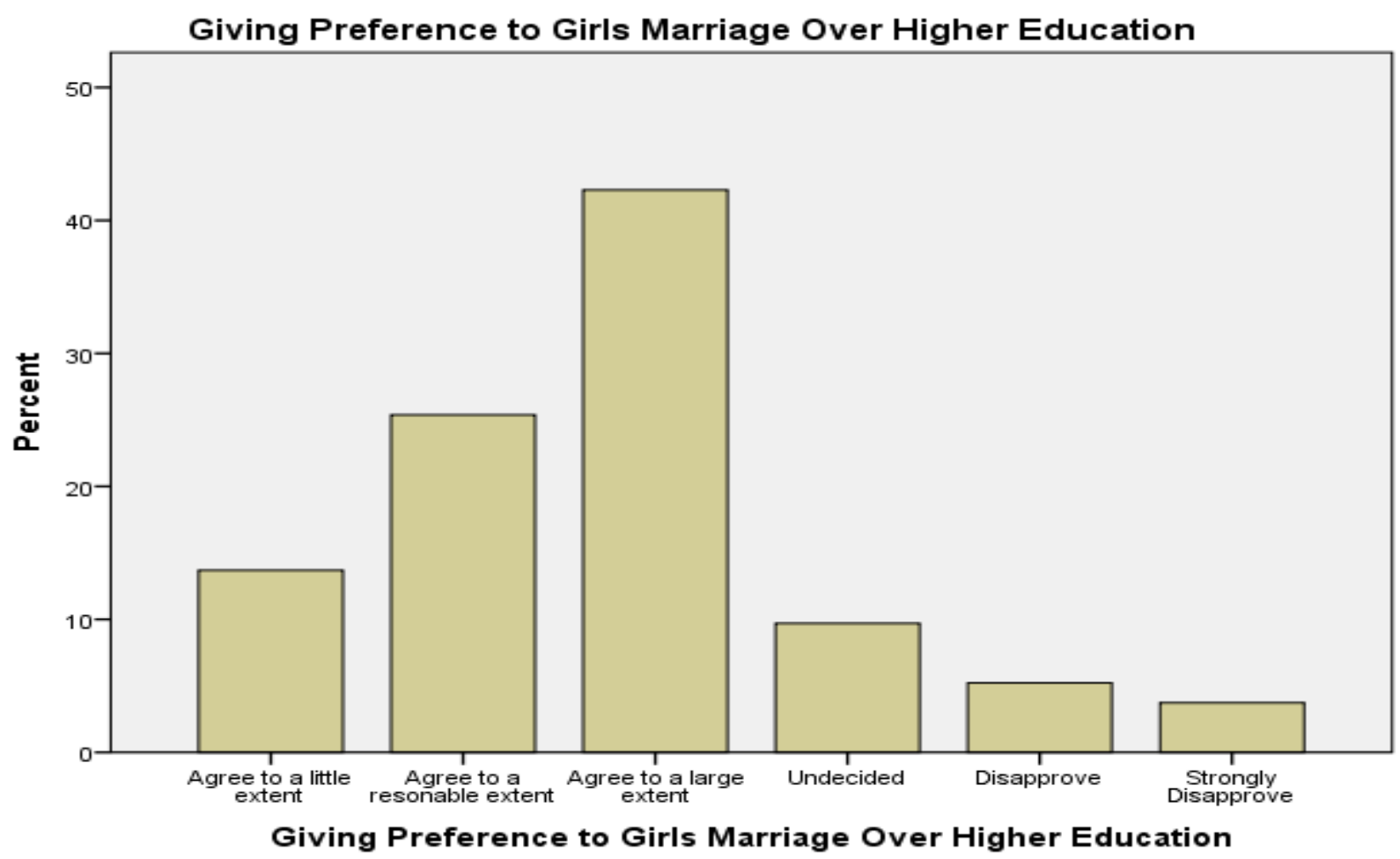

\section{5: Families reluctant to send girls to live in a hostel}

The question was asked to know whether Chitral families are hesitant to send their daughters to higher education or not. Chitral is a far-flung least developed area, women usually have to live in hostels for higher education. Parents usually restrain their daughters to live in hostels, because they feel insecure about their daughter's aloofness from home.

Table 2.5

\begin{tabular}{|l|c|c|c|}
\hline Sr\# no & Choices & \%age & Frequency \\
\hline 1. & Strongly Disapprove & 9.4 & 39 \\
\hline 2. & Disapprove & 6.5 & 27 \\
\hline 3. & Agree to a little extent & 15.1 & 63 \\
\hline 4. & Agree to a reasonable extent & 28.3 & 118 \\
\hline 5. & Agree to a large extent & 31.9 & 133 \\
\hline 6. & Undecided & $\mathbf{8 . 2}$ & $\mathbf{3 4}$ \\
\hline 7. & No response & .7 & $\mathbf{3}$ \\
\hline 8. & Overall responses & $\mathbf{1 0 0}$ & $\mathbf{4 1 7}$ \\
\hline
\end{tabular}


The statistics revealed almost $32 \%$ of the participants opted "Agree to a great extent" little greater than $28 \%$ "Agree to a moderate extent" and 15\% "Agree to a little extent". It shows that most parents in Chitral do not allow their daughters for higher education if they have to live in hostels. From this data, we perceive that either hostel available for women is not safe and secure where females do not feel comfortable or parents feel that by living in hostels their daughters will engage in immoral activities and will challenge the existing social taboos.

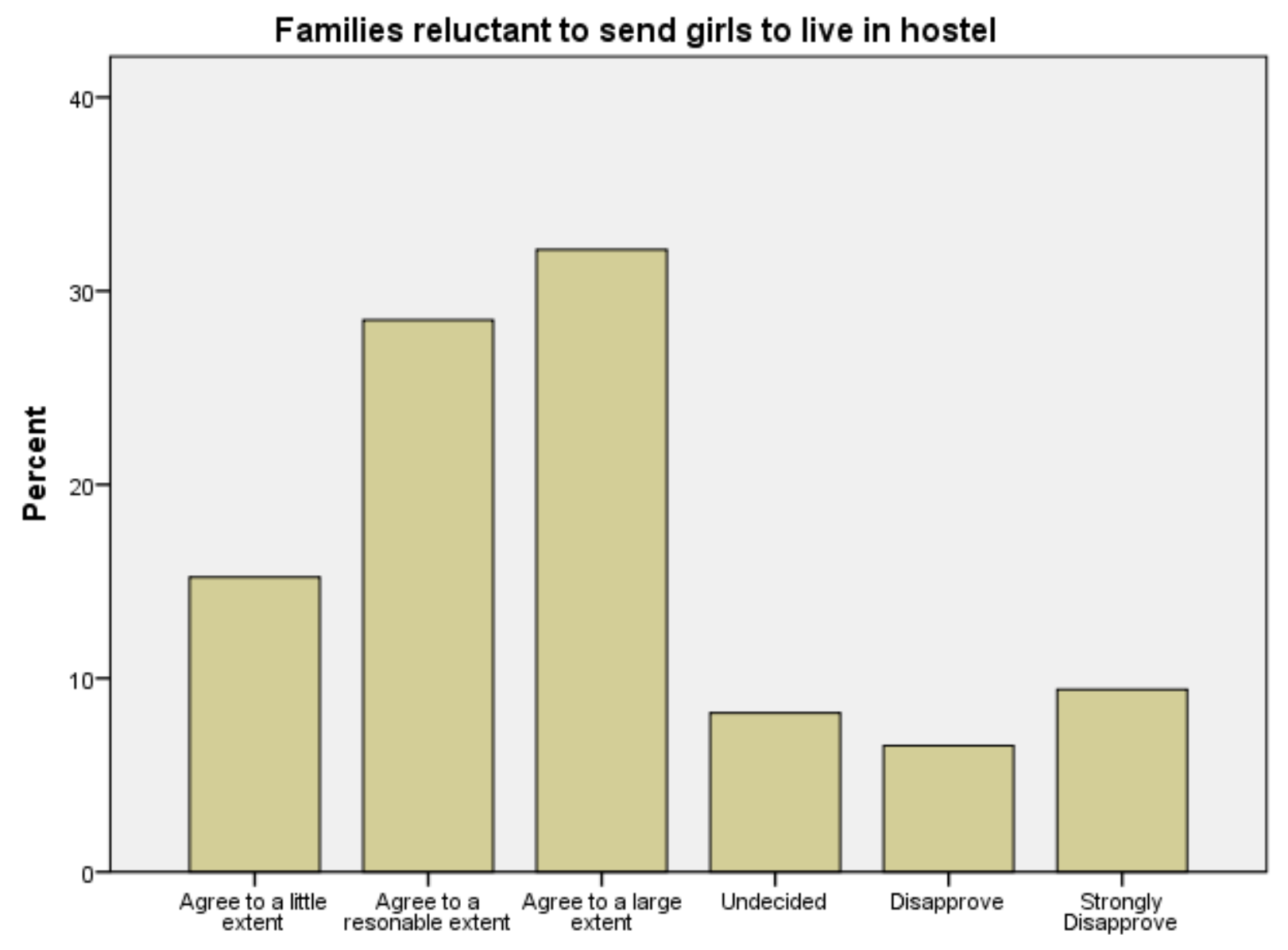

Families reluctant to send girls to live in hostel

\section{6: Co-education makes girls vocal}


To evaluate the perception of the participants about co-education the question was asked whether co-education makes women spoken or not. The question was asked to identify that usually, families are hesitant by the idea that through higher education girls will challenge their existing social taboos.

Table 2.6

\begin{tabular}{|l|c|c|c|}
\hline Sr\# no & Choices & \%age & Frequency \\
\hline 1. & Strongly Disapprove & 13.7 & 57 \\
\hline 2. & Disapprove & 7.9 & 33 \\
\hline 3. & Agree to a little extent & 12.2 & 51 \\
\hline 4. & Agree to a reasonable extent & 14.1 & 59 \\
\hline 5. & Agree to a large extent & 35.3 & 147 \\
\hline 6. & Undecided & 11.3 & 47 \\
\hline 7. & No response & 5.5 & 23 \\
\hline 8. & Overall responses & 100 & 417 \\
\hline
\end{tabular}

The results show that almost $35 \%$ of the participants answered "Agree to a large extent", a little greater than 14 percent "Agree to a moderate extent" and 12.2 percent "Agree to a little extent". With these responses, we discovered that most parents in Chitral believe that co-education has negative impacts on their daughters as they will challenge their existing social norms after getting higher education.

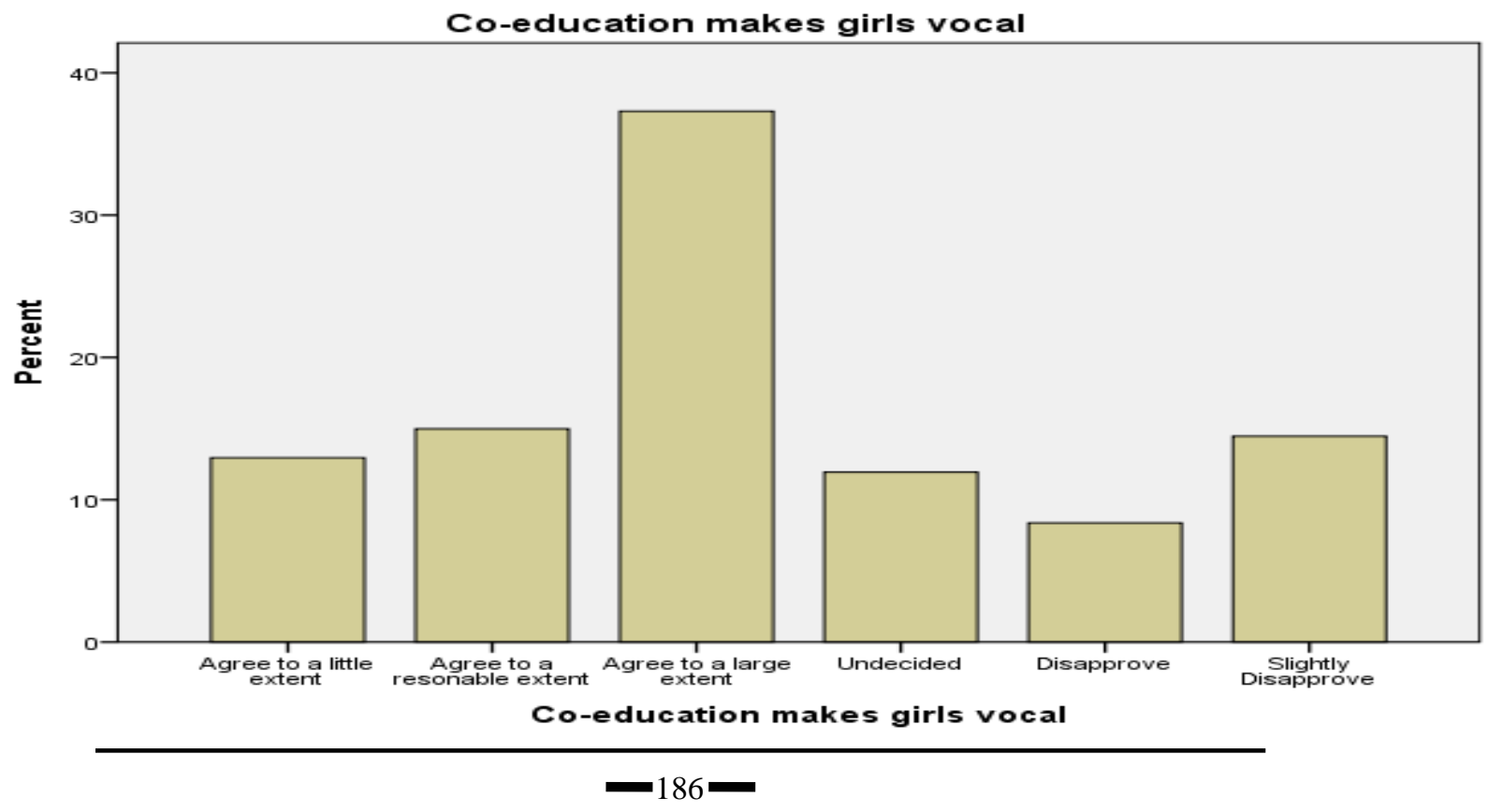




\section{7: Utility of education in future}

Generally, parents in Pakistan are reluctant to permit their daughters for higher education because they perceive that they are less likely to take the benefits of their education in the future. There is a perception that parents believe that investing in girls' education has less usefulness for their family because after the marriage of their daughters they will not take benefits of their education.

Table 2.7

\begin{tabular}{|c|c|c|c|}
\hline Sr. No & Choices & \%age & Frequency \\
\hline 1. & Strongly Disapprove & 12.5 & 52 \\
\hline 2. & Disapprove & 4.6 & 19 \\
\hline 3. & Agree to a little extent & 13.7 & 57 \\
\hline 4. & Agree to a reasonable extent & 37.9 & 158 \\
\hline 5. & Agree to a large extent & 20.6 & 86 \\
\hline 6. & Undecided & 9.6 & 40 \\
\hline 7. & No response & 1.2 & 5 \\
\hline 8. & Overall responses & 100.0 & 417 \\
\hline
\end{tabular}

The question was answered as; 37.9 percent "Agree to a reasonable extent", 20.6 percent "Agree to a large extent 13.7 percent "Agree to a little extent, and the cumulative percentage of those who believe that parents are reluctant to send their daughter for higher education because they do not take benefits of their education in future are slightly greater than those who disagree with the statement.

The opinions of the participants reflect that most families are unwilling to let their daughters pursue higher education because they misunderstand the utility and prospects of their education for society and only think about personal benefits.

The general understanding of not investing in a daughter's education also exists in Chitral. Through this data, we can also perceive that there is a need to encourage women's education in society. The government and NGOs working in Chitral can better address these issues. 


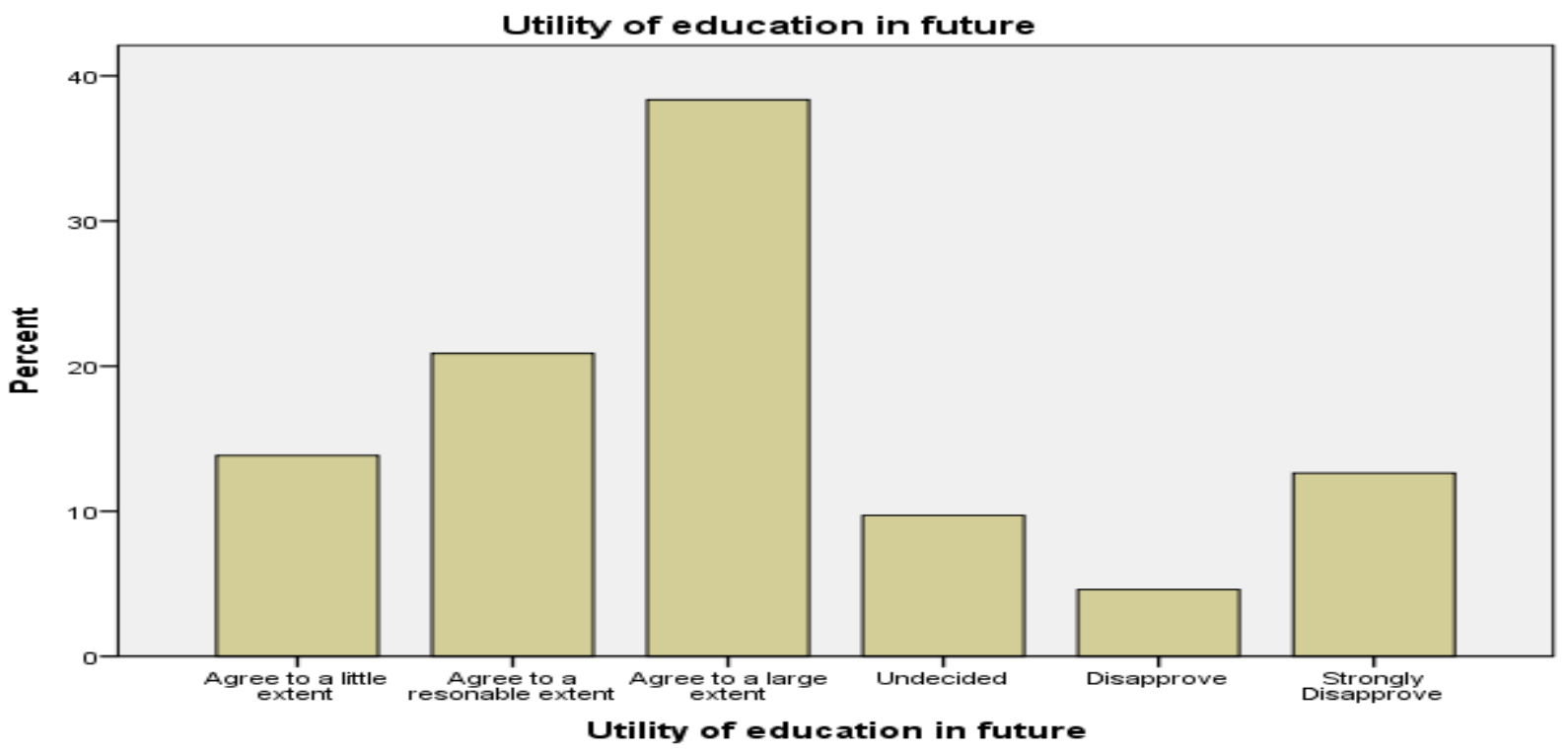

\section{8: Hindrance of Socio-Cultural Setup}

The participants were asked about the socio-cultural implications which adversely affect women's higher education. The question was asked because usually in Pakistan and specifically in the least developed areas socio-cultural taboos hinder women's higher education.

Table 2.8

\begin{tabular}{|l|c|c|c|}
\hline Sr\# no & Choices & \%age & Frequency \\
\hline 1. & Strongly Disapprove & 4.1 & 17 \\
\hline 2. & Disapprove & 7.9 & 33 \\
\hline 3. & Agree to a little extent & 25.7 & 107 \\
\hline 4. & Agree to a reasonable extent & 23.3 & 97 \\
\hline 5. & Agree to a large extent & 22.8 & 95 \\
\hline 6. & Undecided & 13.2 & 55 \\
\hline 7. & No response & 3.1 & 13 \\
\hline 8. & Overall responses & 100 & 417 \\
\hline
\end{tabular}

The results show that; a little less than 26 percent opted for "Agree to a little extent", slightly greater than 23 percent "Agree to a reasonable extent", little less than 23 percent "Agree to a large extent". The study revealed that students who have agreed that sociocultural environment restricts girl's education are greater than those who disagree with 
the statement, hence it's obvious from the results that socio-cultural environment has negative implications on women's higher education.

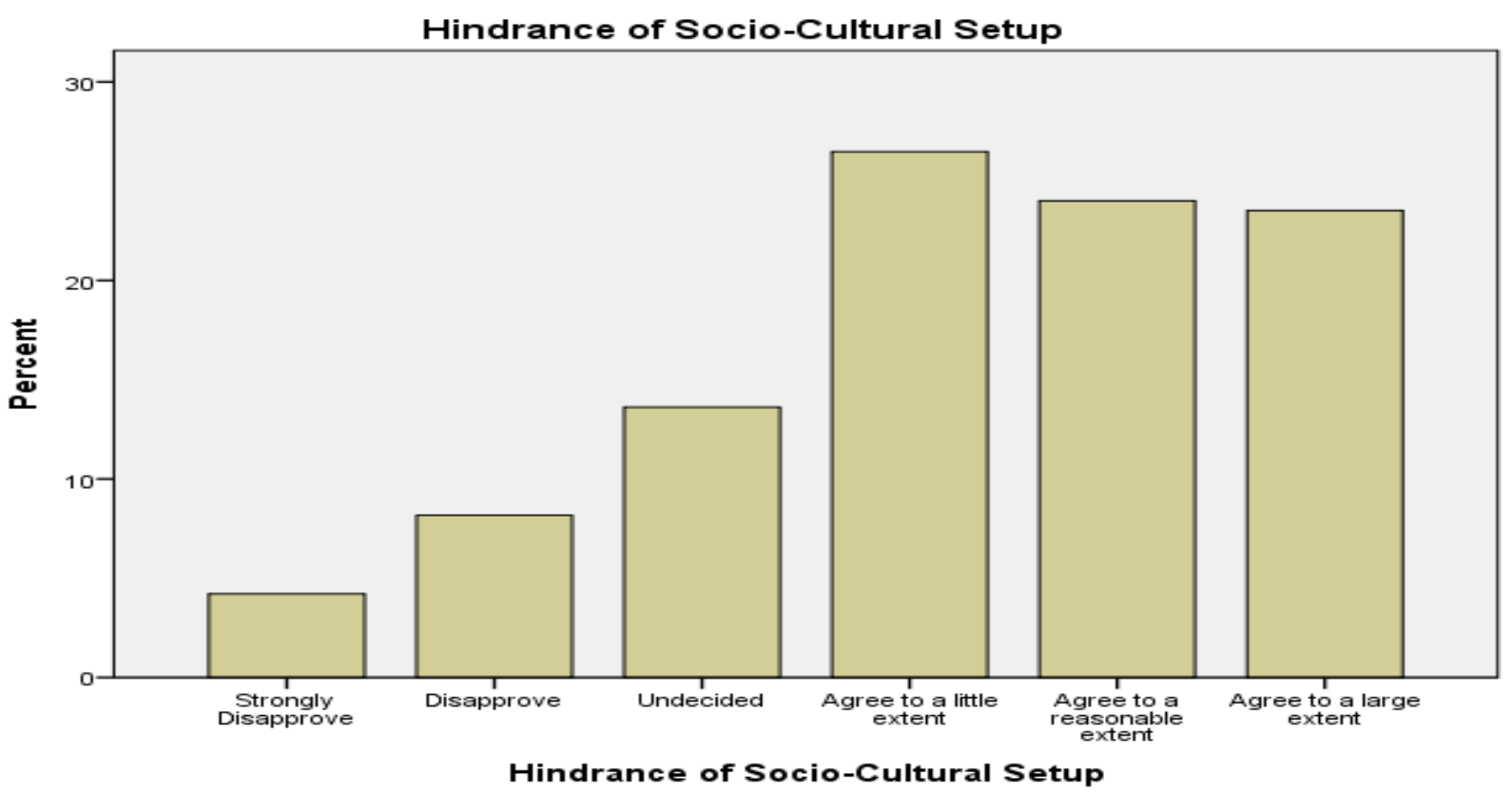

\section{9: Use of Abaya or Shawal while traveling to University}

The participants were asked if they use Abaya or Shawal while traveling to University. The question was asked because girls usually in Pakistan and mostly in backward areas are usually forced by the parents to wear Abaya or Shawal. Most families make Abaya or Shawl obligatory for their daughters if they have to get admission in higher education.

\begin{tabular}{|l|c|c|c|}
\multicolumn{5}{|c|}{ Table 2.9} \\
\hline Sr. No & Choices & \%age & Frequency \\
\hline 1. & Not at all & 11.5 & 48 \\
\hline 2. & Very frequently & 62.6 & 261 \\
\hline 3. & Seldom & 13.7 & 57 \\
\hline 4. & Always & 10.3 & 43 \\
\hline 5. & No response & 1.9 & 8 \\
\hline 6. & Overall responses & 100 & 417 \\
\hline
\end{tabular}

The statistics show that almost 63 percent of the respondent opted "Very Frequently", a little less than 14 percent opted "seldom", and 10.3 percent "Always". The majority of women who participated in the study mostly wear Abaya or Shawal while traveling to university, which shows that wearing Abaya or Shawal is part of their culture or some 
possibilities wearing Abaya or Shawal is a guarantee for them from their families if they have to study in higher education.

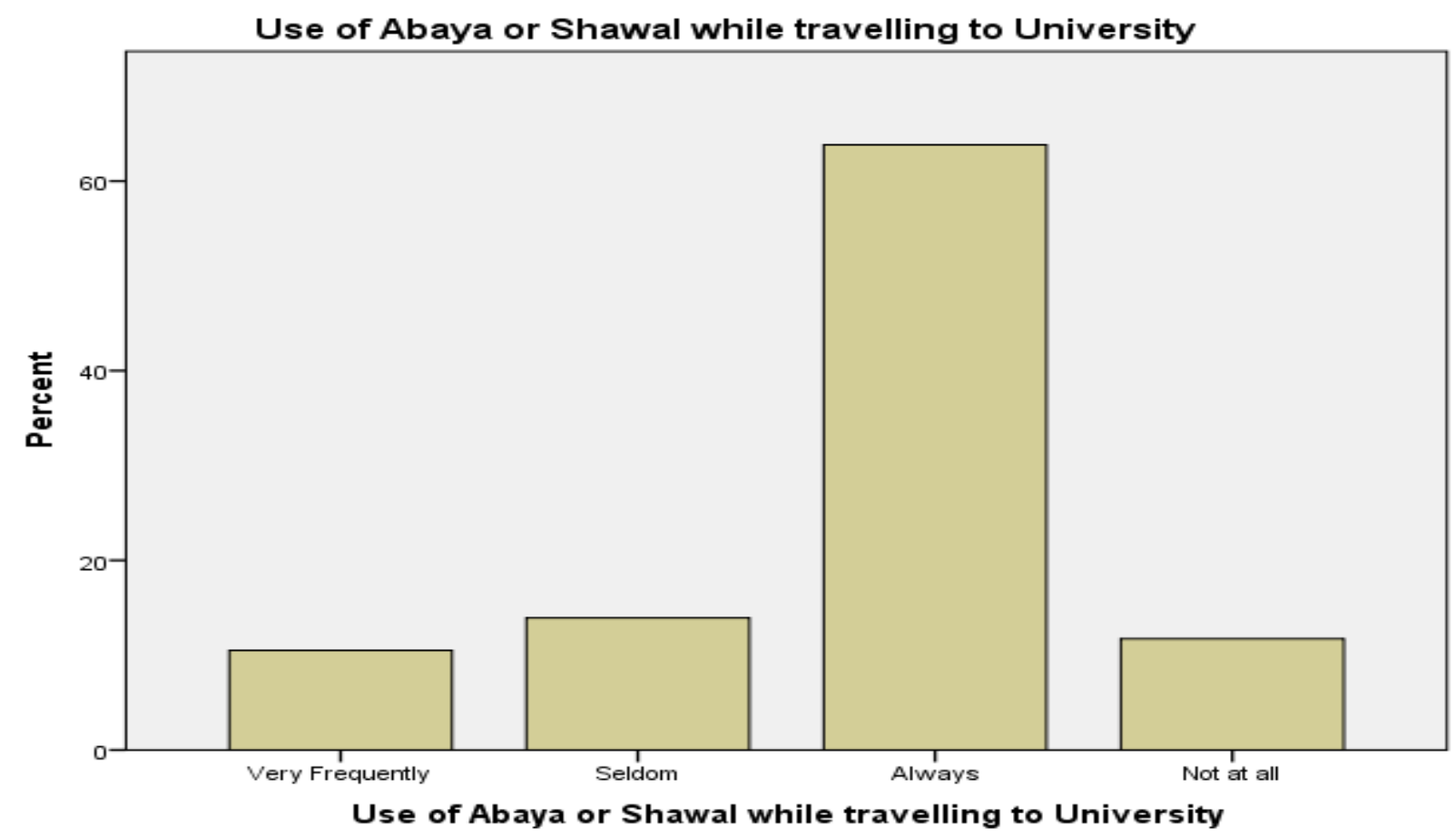

\subsection{0: House chore Burden}

The question was asked from the participants to find out how much house chore burden hinders their higher education. The literature review says that the majority of women in Pakistan face hurdles and constraints in higher education because of the house chore burden. Labor division in families has limited women to stay indoors which limits women's participation in other walks of life.

Table 2.10

\begin{tabular}{|c|c|c|c|}
\hline Sr. No & Choices & \%age & Frequency \\
\hline 1. & Live in hostel & 25.4 & 106 \\
\hline 2. & Not at all & 16.1 & 67 \\
\hline 3. & Very frequently & 23.5 & 98 \\
\hline 4. & Very often & 16.1 & 67 \\
\hline 5. & Seldom & 18.0 & 75 \\
\hline 6. & No response & 1.0 & 4 \\
\hline 7. & Overall responses & 100.0 & 417 \\
\hline
\end{tabular}


The statistics revealed that almost $24 \%$ of the participants opted "very frequently", $18 \%$ "Seldom", 16\% "Very often". The data revealed that the majority of girls in Chitral face hurdles and constraints in their higher education because of the house chore burden. Families should accommodate their daughters by reducing their household responsibilities so that they can easily pursue their higher education.

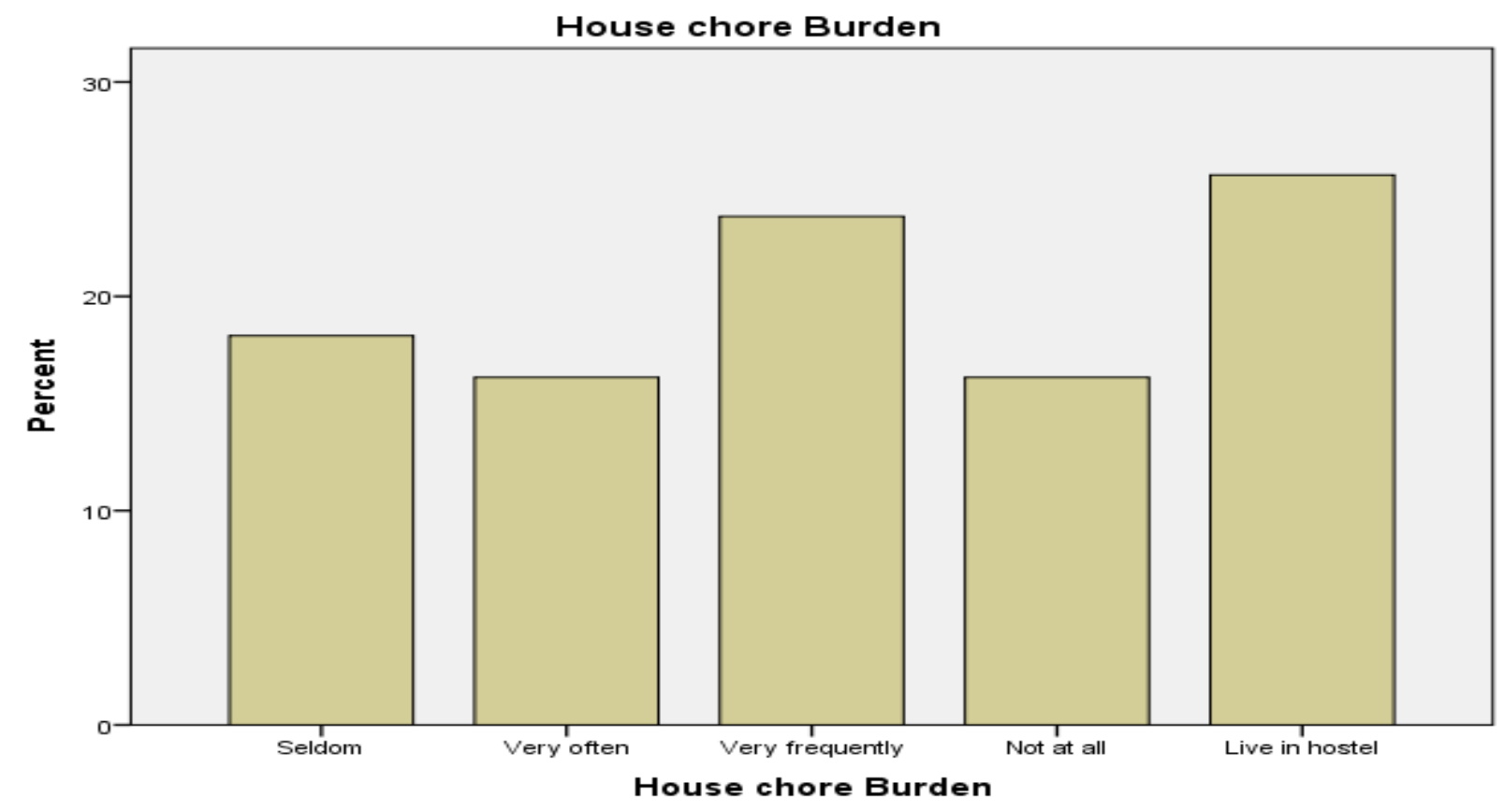

\section{FINDINGS AND DISCUSSION}

The study reveals that socio-cultural factors affect women higher education in the following ways;

\section{1: Gender Discrimination in Provision of Educational Resources}

Gender equality enhances the social development of a society. It can be gaged in terms of economic progress, educational advancement, political development, health care, social and legal rights given to the members of the society. Investing in female education is a practice for enhancement and betterment and poverty elevation technique in advanced countries as it gives back high social rate (Byron, \& Örnemark, 2010). UNESCO report of 2007 says that; Pakistan has the broadest gender gap in education and discrimination against women which is persistent in almost all walks of life (Lynd, 2007).

In Pakistan, women face apparent and subtle gender discrimination almost at every stage 


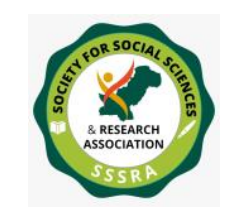

Pak. Journal of Int'L Affairs, Vol 4, Issue 1 (2021)

Socio-Cultural Factors Affecting ...

of life. Gender segregation generates economic reasons for prioritizing boys' education. Girls who marry typically go to live with, and contribute to, their husband's family, whereas sons are anticipated to stay with their parents, so sending sons to school is seen as a valuable investment within the family's economic future as compared to daughters.

In Chitral, women face economic hardships within their homes, as the prioritization of capital investment is higher as compared to boys. Chitral is a traditional parochial society, where social and cultural taboos influence the social fabric of the society. These socio-cultural misconceptions directly affect women's position in society. Most parents in Chitral perceive that investing in girl's education provides the least benefits to their own family and more benefits to the girl's in-laws, therefore instead of educating their girls, parents prioritize their boys. In Chitral, families perceive that, presumably, sons are the ones who take care of their parents when they come to old age, so parents believe that investing in boys' education is a source of retirement investment for them.

Gender discrimination in terms of education has negative implications over society. Which is also against the Islamic and liberal understanding, negates the constitution of Pakistan and Universal Declaration of Human Rights values. Society will develop and flourish through an inclusive development strategy, where male and female members of the society take an active part in the uplift of the society.

\section{2: Cultural Norms Restrict Girls' Higher Education}

In the patriarchal setup of Pakistan, women are lagged as secondary citizens as compared to the male counterpart. Similarly, the education system of Pakistan discourages women's participation as they remain at the bottom level of focus of attention. Gender disparity has reduced opportunities for women in the educational field. The traditional setup of society where women are assumed and limited to the private sphere still dominates Pakistan's society. Socio-cultural norms strongly affect women's status in society. The gender disparity in Pakistan is deep-rooted and human rights violations under the constitution are extensive. Being a far-flung area of Khyber Pakhtunkhwa, Chitral presents its unique culture which is different from other parts of Pakistan in its characteristics including; traditions, customs, values, rituals, and ethnic heterogeneity. The status of women in the social fabric of Chitral represents a clear distinction and space in public and private space and division of role and responsibilities between man and women. Women are usually limited to their private spaces like homes and neighborhoods because of cultural prospects and seclusion. Women usually spent their 16 to 18 hours doing house chores. Maintenance of kitchen, gardening, grazing cattle, collecting woods, working on farms, 


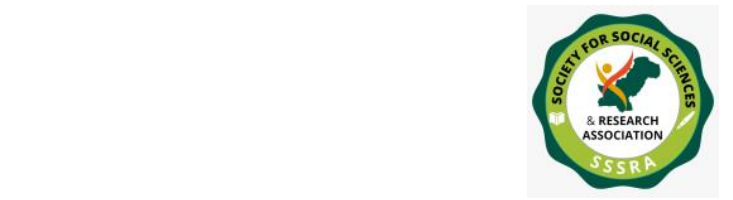

Pak. Journal of Int'L Affairs, Vol 4, Issue 1 (2021)

Socio-Cultural Factors Affecting ...

washing clothes, production of handicrafts has remained the exclusive domain of women in Chitral.

Cultural norms have also restricted the mobility of women to a great extent. Permission of man-often the father, husband, brother is essential for women for their public mobility. In Public spaces, women always observe Purdah by wearing Hijab or Burqa. This paradigm is slowly and gradually shifting and women's role in the public sphere is increasing day by day. But still, there has to be done a lot to change the minds of people according to the needs and requirements of the modern world where men and women should take an active part in the public sphere of life.

\section{3: Early Marriages of Girls}

According to a report published by Human Rights Watch in 2018, "In Pakistan early marriage of girls is a very serious issue, some families believe that beyond a certain age girl should not continue their education". The report further highlights that the misconception of prioritization of marriage over education is reducing day by day, but still, more practical steps must be taken to further curve the issue, as most parents are of the view that boys and girls are equal but practically it is not ( Martinez, 2018, November 12).

According to a report of UNICEF, there is a direct connection between early marriage and a low level of education, as in Pakistan 21\% of girls marry before the age of 18 and $3 \%$ marry before the age of 15 (Asif, 2018, June 15). The ratio and is greater in tribal and least developed areas as compared to urban areas. Pakistan is at number $6^{\text {th }}$ among the highest absolute number of women married or in union before the age of 18 in the world ("What's the Child Marriage Rate? How Big or an Issue Is Child Marriage?" n.d.) In Pakistan child marriage has always been a very serious issue which creates lots of hurdles for girl's education. Early marriages disturb and put a stop on girls' education, as familial and societal pressure does not allow girls to proceed with their education. Early marriage of girls is a very serious concern in Chitral. This study exposed that women in Chitral face problems because of early marriage. Early marriage not only affects the education of a girl but is also a human rights violation. To tackle this issue, the role of government and civil society is very necessary. Families should need to be educated about the problems related to the early marriages of girls.

\section{4: Perception of Co-education}

The co-education system is exercised almost everywhere in the world. There is a system of co-education in public and private sector colleges and universities in Pakistan, but 


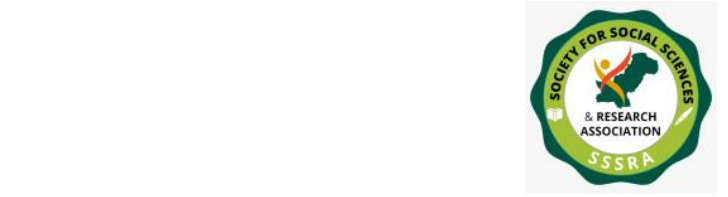

there are also separate institutions for boys and girls. The understanding of co-education in rural areas is different as compared to urban areas of Pakistan. People in the least developed rural areas did not always welcome the system of co-education. Social taboos and misconceptions hinder families to allow their daughters to send to a co-education system. Chitral is the least developed area in terms of infrastructure, educational institutions, and traveling facilities. The only public sector university was established in 2017. The system of education adopted by the university is co-education. This study reveals that the perception of families about the co-education system in Chitral is somewhat negative. Most families are reluctant to send their daughters to co-education, and those parents who have permitted their daughters to study in co-education have been left with no other options because there is no separate university for girls and coeducation becomes an unavoidable entity for them.

To enhance the system of higher education among women in Chitral, the government should establish a female university until the society and families develop a positive understanding of the co-education system.

\section{5: Use of Girl's Education in Future}

In Pakistan, it is generally perceived that families do not allow their daughters for higher education because they perceive that women do not make use of their education in the future. There is a taboo that girls should not study when they come to a certain age. The understanding of girl's education is different among different sections of society. This study reveals that in Chitral girls are also deprived of higher education because families believe that they do not make use of their education further. Girls are usually taken away from schools when they reach puberty. Instead of struggling for their daughter's education, families struggle for her marriage arrangements. These socio-cultural taboos hinder and restrict girl's education.

\section{6: Household chore Burden}

According to a report published by UNICEF girls between the age of 5 to 14 years spend 40 to 50 percent more time doing unpaid household chores like; collecting wood, bringing water compared to boys of their age (United Nations Children's Fund, 2019). Household work is considered to be a primary deterrent to girls' education. In backward areas, women suffer excessively as compared to urban areas of Pakistan. Social and cultural taboos restrict women within the four walls of houses. Women are only meant for them as a tool for reproduction and they only must maintain the house chore. 


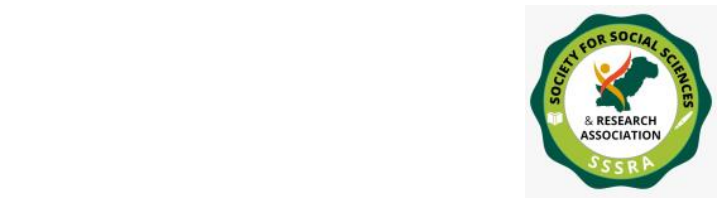

Pak. Journal of Int'L Affairs, Vol 4, Issue 1 (2021)

Socio-Cultural Factors Affecting ...

In the Chitral district house chore burden is a great difficulty that restricts women's higher education. The general understanding among the people of Chitral "Xur duro sum shell" has limited women inside their homes. Usually is Chitral people believe that girls should only be able to read a writer and that is enough education for them to survive. Which negates the modern standards of education where girls cannot compete with the contemporary challenges.

\section{7: Distance of Educational Institution}

While receiving higher education in Chitral women face lots of challenges and hurdles because of the distance of educational institutions. Chitral is an underdeveloped area in terms of infrastructure. The only public sector university was established in 2017. Still, women have to travel long distances to reach university which is located in the city area of Chitral. The university is newly established therefore only a few faculties and departments are operational Students from Chitral mostly travel to other parts of Pakistan to pursue higher education. The only developed area which is easily accessible to them in Peshawar, which almost takes 12 hours to reach. To pursue higher education girls, have to face many difficulties at home as deciding and letting their daughter live in another city is difficult for parents. Socio-cultural constraints did not let parents allow their daughter to study in other cities. Parents feel that permitting their daughters to pursue education in other cities is against their existing social norms.

\section{8: Recommendations}

After studying and analyzing thoroughly the difficulties and obstacles faced by women in Chitral in their higher education the researcher has come up with certain measures and recommendations to enhance women's education. NGOs and Government Organizations should work to highlight women's issues and the role of higher education for women by arranging seminars and conferences at different levels.

The Government of Khyber Pakhtunkhwa needs to have policies and approaches to enhance educational resources which is beneficial for the society and the whole country. Role of the local community is also important to change the social taboos while creating a favorable environment for women's education and to discourage those norms and traditions which hinder women's higher education and their employment. Educational institutions should also play their role to build family and community support to guarantee girls' education in higher education equal to that of boys. University of Chitral needs to be updated by establishing new programs for MPhil and Ph.D. and by introducing new faculties and departments. New Private and Government hostels for girls need to be established as the existing hostels do not meet the needs and requirements of 


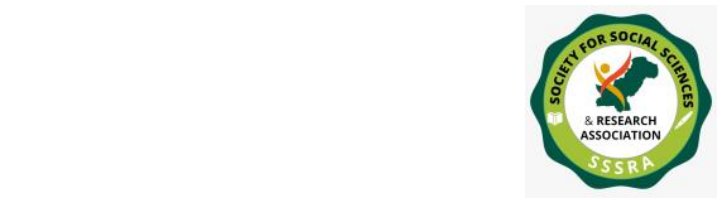

girls in higher education. The role of NGOs is very necessary for the development and progress of society. The government should help and promote NGOs working for higher education. There is a need to establish another university in upper Chitral to facilitate the students coming from far-flung areas of Chitral.

\section{4: Conclusion}

Education plays a phenomenal role in the progress and uplifting of society. Society will change socially, economically, and politically if the society adopts an inclusive educational strategy, where males and females both participate equally in the development of a country. In Pakistan generally and in Chitral particularly there is a need to seriously address the issues about women education and especially higher education. The prevailing gender discrimination, socio-cultural taboos, continue to alleviate against the effective introduction of social change. Different NGOs and Human Rights Commission are working significantly to provide facilities to women in higher education, but still, the proportion is less and it needs more attention and work to make it equal in the future. In Pakistan generally and Chitral particularly women face lots of challenges in higher education. The burden of the household, domestic violence against women, social and societal taboos have an undesirable influence on women's education. Societies also deter females to have appropriate professions or services.

Financial constraints, Gender discrimination, negative perception of co-education, and distance of educational institutions have undesirable implications on women's higher education. Through higher education, women can enjoy greater life of the mind as it changes the society towards peace and prosperity. But unfortunately, in Chitral different factors directly affect women's higher education such as; early marriages' lack of consciousness about education, the workload at home, combined family structure, and socio-cultural taboos.

Thus, it appears that socio-cultural taboos have negative implications on women's education. There are so many factors responsible which curtail women's education. The civil society, professionals, and government should work to curtail these issues to enhance women's higher education, by taking effective measures, because "if you educate a man, you educate an individual but, if you educate a woman, you educate a nation". 


\section{Reference}

AASA Consulting \& GRHO. (2014). Situation Analysis \& Baseline Surveys For Poverty Reduction through Rural Development in KPK, FATA \& Balochistan. PPAF. Zotero. https://studylib.net/doc/6686847/situation-analysis-and-baselinesurveys-for-poverty-reduction

Altekar, A. S. (1938). The Position Of Women In Hindu Civilisation Internet Archive. https://archive.org/details/in.ernet.dli.2015.100033/page/n3

Asif, Umair (2018, June 15). Early Marriage Puts a Stop to a girls education- We need laws that protect underage girls.Their World. https://theirworld.org/voices/child-marriage-laws-needed-inpakistan-to-protect-girls-school-education.

Byron, G., \& Örnemark, C. (2010).Gender equality in Swedish development Sida.www.bridge.ids.ac.uk/reports/re53.pdf

Choudhry, A. N., Mutalib, R. A., \& Ismail, N. S. A. (2019). Socio-cultural factors affecting women economic empowerment in Pakistan: A situation analysis. International Journal of Academic Research in Business and Social Sciences, 9(5), 90-102.

Countrymeters. (2019). Pakistan Population Clock. https://countrymeters.info/en/Pakistan.

Dawn. (2003, February 6). Chitral has highest literacy rate. Dawn News. https://www.dawn.com/news/81119

Farooqi, G. Hammad, (2012, Feburary 22) 14 Languages Spoken in Chitral. Pamir Times. https://pamirtimes.net/2012/02/22/14languages-spoken-in-chitrall

Kanji, G., \& Ali, T. (2006). School Improvement: A Case from the Northern Areas in Pakistan. In I. Farah \& B. Jaworski (Eds.), Partnerships in Educational Development. (pp. 193-205). Oxford: Symposium Books.

Lund, A. A. (2019, January 14). Gender discrimination in Pakistan. Daily Times. dailytimes.com.pk/343842/gender-discrimination-inpakistan-3/

Liljergren, M. (2002). The Hidden Key: Attitude towards the education of women and Girls in Northen Pakistan. [Stockholm University]. 
https://www.sil.org/system/files/reapdata/19/05/55/19055544673414 574071689916732291247857/Maarit_Women_Education.pdf.

Lynd, D. (2007). The Education System in Pakistan: Assessment of the National Education Census. UNESCO. https://www.heartresources.org/doc_lib/the-education-system-in-pakistan-assessmentof-the-national-education-census/.

Martinez, E. (2018, November 12). Shall I feed my daughter, or Educate her? Human Rights Watch. https://www.hrw.org/report/2018/11/12/shall-i-feed-my-daughter-oreducate-her/barriers-girls-education-pakistan.

Murtaza, K. F. (2012). Women Empowerment Through Higher Education in Gilgit Baltistan. International Journal of Academic Research in Business and Social Sciences, 2(9), 343-367.

National Assembly of Pakistan.(2012, Feburary 28). The Constitution of the Islamic Republic of Pakistan: A 1973 Pakistan's Third Constitution.

http://www.na.gov.pk/uploads/documents/1333523681_951.pdf.

Noreen, G., \& Khalid, H. (2012). Gender empowerment through women's higher education: Opportunities and possibilities. Journal of Research and Reflections in Education, 6(1), 50-60.

Oxaal, Z. (1997). Education and Poverty: A Gender Analysis (Vol. 53). Sussex: Institute of Development Studies at the University of Sussex.

Pakistan Alliance for Girls Education. (2020, June 18). Education Budget of Pakistan:Promoting Gender Equity In Education. P.A.G.E. https://page.org.pk/education-budget-ofpakistan/\#: :text=81.2\%20billion\%20for\%20the\%20ongoing,the\%2 0lowest\%20in\%20the\%20region.

Pakistan Economic Survey 2007-2008. (2008). Education. finance.gov.pk/survey/chapters/10-Education08.pdf.

Pardhan. A. (2005). Booni Valley Women,s Perceptions of Schooling: Hopes and Barriers. International Education Journal, 6(4), 438-445.

Rashid, Dr. K., \& Mukhtar, S. (2012). Education in Pakistan: Problems and their Solutions. International Journal of Academic Research in Business and Social Sciences, 2(11). 332.

Razzaq, A. (2016, June 30). In Chitral, Women Cannot be singers. The Express Tribune. https://tribune.com.pk/story/1133503/chitralwomen-cannot-singers. 
Ronaq, S. (2014, March 25). 11 Key Traits of Pakistani Culture. Sharnoff's Global Views. https://www.sharnoffsglobalviews.com/pakistaniculture-traits-244/

Shah, R. (2015). Interpretations of Educational Experiences of Women in Chitral, Pakistan. [University of South Florida]. Graduate Theses and Dissertations.

Shaukat, S., \& Pell, A. W. (2017). The Impact of Socio-cultural factors on females passing through Higher Education in Pakistan. Eurasian Journal of Educational Research. 17(71), 193-214.

The Global Human Capital Report 2017. (2017, September 13). World Economic Forum. https://www.weforum.org/reports/the-globalhuman-capital-report-2017/

The Nation. (2015, February 21). Women Education in Pakistan. The Nation. nation.com.pk/21-Feb-2015/women-education-in-pakistan

United Nations Children's Fund. (2019). For Every Child, Every Right: The Convention on the rights of the child at CrossRoads. https://www.unicef.org/reports/convention-rights-child-crossroads2019.

University of Chitral. (2021). University of Chitral. https://uoch.edu.pk/. 